\title{
On the cointegration and causality between oil market, nuclear energy consumption, and economic growth: evidence from developed countries
}

\author{
Hanan $\operatorname{Naser}^{1}[$ \\ ${ }^{1}$ Faculty of Business Studies, Arab Open University, Rd No 3206, A’ali, Bahrain
}

Received: 24 October 2016/Revised: 6 February 2017/Accepted: 13 February 2017/Published online: 9 March 2017

(C) Joint Center on Global Change and Earth System Science of the University of Maryland and Beijing Normal University and Springer-Verlag Berlin Heidelberg 2017

\begin{abstract}
This study uses Johansen cointegration technique to examine both the equilibrium relationship and the causality between oil consumption, nuclear energy consumption, oil price and economic growth. To do so, four industrialized countries including the USA, Canada, Japan, and France are investigated over the period from 1965 to 2010. The cointegration test results suggest that the proposed variables tend to move together in the long run in all countries. In addition, the causal linkage between the variables is scrutinized through the exogeneity test. The results point that energy consumption (i.e., oil or nuclear) has either a predictive power for economic growth, or feedback impact with real GDP growth in all countries. Results suggest that oil consumption is not only a major factor of economic growth in all the investigated countries, it also has a predictive power for real GDP in the USA, Japan, and France. Precisely, increasing oil consumption by $1 \%$ increases the economic growth in Canada by $3.1 \%$., where increasing nuclear energy consumption by $1 \%$ in Japan and France increases economic growth by 0.108 and $0.262 \%$, respectively. Regarding nuclear energy consumption-growth nexus, results illustrate that nuclear energy consumption has a predictive power for real economic growth in the USA, Canada, and France. On the basis of speed of adjustment, it is concluded that there is
\end{abstract}

Electronic supplementary material The online version of this article (doi:10.1007/s40974-017-0052-0) contains supplementary material, which is available to authorized users.

This study has been conducted for pure academic purposes and without any financial funding.

Hanan Naser

hanan.naser@aou.org.bh bidirectional causality between oil consumption and economic growth in Canada. On the other hand, there is bidirectional causal relationship between nuclear energy consumption and real GDP growth in Japan.

Keywords Oil prices - Nuclear energy consumption - Oil market $\cdot$ Economic growth $\cdot$ Cointegration

\section{Introduction}

Since the quick developing of world energy demand has effectively raised concerns over security of energy supply and abundant environmental drawbacks, numerous researchers have empirically examined the causal relationship between energy consumption and economic growth. Virtually, either existence or lack of causality has important implications in designing effective energy policies. For example, (1) a feedback relation between energy consumption and economic growth suggests that energy conservation policies that aim to reduce energy use may lead to economic deficiencies, (2) causality from economic growth to energy consumption implies that energy conservation policies have minimal unfavorable or no impact on economic growth, (3) causality from energy consumption to economic growth shows that energy consumption stimulates economic growth and accordingly economic growth is reliant on energy consumption, which reveals that negative energy shocks and energy conservation policies may slow down economic growth. Furthermore, any energy conservation policy which restricts energy consumption may lead to a decrease in economic growth, and (4) the neutrality between energy consumption and 
economic growth allows policy makers to develop energy policies that are not dependent on economic activity. Therefore, determining the nature of the relationship between energy usage and economic growth plays a vital role in selecting an appropriate energy policy.

Until now, crude oil is still considered the second largest source of energy consumption. Therefore, one strand of the empirical literature has focused on analyzing the relationship between oil consumption and economic growth, which is not only a fundamental energy source in industrialized countries, but also poses a major threat for environmental problems caused by excessive build-up of carbon dioxide. Oil is also an essential source for supporting development of an economy. Moreover, oil prices are extremely volatile and unpredictable. Thus, many countries, specially industrialized countries, have put a great effort on both promoting oil preservation strategies and diversifying energy sources to find a secure, cheap and non-GHG-emitting energy supply in order to solve the above issues (Fiore 2006; Vaillancourt et al. 2008; Wolde-Rufael and Menyah 2010). To combat energy and environmental configurations, the International Energy Agency (IEA 2008) has noted that the nuclear power may accommodate these conditions. Apergis et al. (2010) suggest that since the nuclear energy provides a long-run and high-performance option, it is an effective environmental policy tool that may provide solutions for global climate control as well as to energy security problems. Besides, the development of nuclear energy can prompt the overflow impact of vast innovation and can advance the profitability of work, capital, and other useful production fundamentals (Yoo and Jung 2005). Thus, in order to consider future economic development and energy demands, the development of nuclear energy is expected to be a valid option in the globally sustainable development strategy (Vaillancourt et al. 2008). Identifying the direction of causation between nuclear energy consumption and economic growth provides important information for better understanding the logical reason of investing in nuclear energy for economical concern or for environmental and social concerns. There are several reasons to concentrate on examining causal linkages between nuclear energy consumption and economic growth. First of all, Apergis and Payne (2010a) note that researchers need to shed the light on the impact of using nuclear power as an alternative to fossil fuels on economic growth for sustainable development. In addition, higher fossil fuel prices allow nuclear power to become economically competitive with the generation from coal, natural gas, and liquids despite the relatively high capital and maintenance costs associated with nuclear power plants. Moreover, higher capacity utilization rates have been reported for many existing nuclear facilities (EIA 2009). Vaillancourt et al. (2008) have emphasized that as countries are committed to meet the global growing demand for energy, long-term energy and environmental strategies have promoted the transition from fossil fuels to other clean energy sources such that of renewable or other non-greenhouse gas-emitting energy sources.

Given that few studies attempt to examine the causal linkage between the proposed energy consumption variables an economic growth such that of Lee and Chiu (2011a, b) and Naser (2014, 2015a, b), the purpose of this paper is to fill this gap by investigating the long-run relationship between oil consumption, nuclear energy consumption, oil price, and economic growth using Johansen cointegration analysis.

In particular, this paper runs an investigation among four industrialized countries, named the USA, Canada, Japan, and France, over the period from 1965 to 2010. Empirical results provide information about the nature and direction of linkage between nuclear energy consumption and economic growth, oil consumption and economic growth, and oil prices and economic growth. Each country has been examined separately to account for country specific characteristics such as energy patterns and economic crisis. The main reason for studying the long-run relationship between oil consumption, nuclear energy consumption, and economic growth is that both oil and nuclear energy play an important role in designing effective energy policies that accounts for both economic growth and environmental protection. This also plays a vital role in implementing these types of policies.

Results of cointegration analysis illustrate that at least one energy input cannot be excluded from the cointegration space. This implies that a long-run relationship exists between energy consumption and economic growth. As far as the results of cointegration vectors normalized with respect to real GDP growth, the coefficients of oil consumption are found to affect the level of economic growth significantly and positively in the USA, Canada, and France. This finding implies that the use of more oil stimulates the real GDP growth. Alternatively, nuclear energy consumption has been found to influence economic growth positively and significantly in Japan and France. Although oil price is found to be exogenous to the long-run equilibrium error in most countries, it is endogenous and negative in the case of Canada. Furthermore, results from the parsimonious vector equilibrium correction model (PVECM) show that oil consumption has predictive power for economic growth in the USA, Japan, and France. Additionally, there is a feedback impact between oil consumption and real GDP growth in Canada. Hence, oil can be considered an important factor to output growth in this country. Regarding the nuclear energy consumptiongrowth nexus, there is a bidirectional relationship between nuclear energy consumption and output growth in Japan. 
Moreover, nuclear energy consumption is found to have information that could predict real GDP growth in the USA, Canada, and France.

In what follows, a literature review is provided in Sect. 2. Section 3 describes the econometric methodology. Section 4 illustrates the data sources and definitions of the variables. Section 5 shows the empirical results, and a conclusion is provided in Sect. 6.

\section{Literature review}

The causal linkage between energy consumption and economic growth has extensively been examined in the literature since the seminal work of Kraft and Kraft (1978). However, due to the fact that empirical results are conflicting, a coherent conclusion cannot be build up. To illustrate, although Kraft and Kraft (1978) show that there is a causal relationship running from real GNP to gross energy inputs in the USA, Akarca and Long (1980) find that the relationship is neutral after excluding the period of recession. They argue that the causal order suggested by Kraft and Kraft (1978) is spurious and it is sensitive to the sample period.

While this is the case for the USA, Mehrara (2007) examines the causal relationship between the energy consumption and GDP in a panel of 11 selected oil exporting countries. The results show that a unidirectional strong causality from economic growth to energy consumption is exist for the oil exporting countries. However, Mahadevan and Asafu-Adjaye (2007) propose that there is bidirectional causality between economic growth and energy consumption only in the developed oil exporting countries in both the short and long runs. Ozturk (2010) have expanded the data set to cover 51 countries including: low-income group, lower-middle-income group, and upper-middle-income group countries. The empirical results of their study suggest that energy consumption and GDP are cointegrated for all three income group countries. In addition, the panel causality test results reveal that there is long-run Granger causality running from energy consumption to economic growth for low-income countries, and there is bidirectional causality between energy usage and GDP for middle-income countries. ${ }^{1}$ Some other studies attempt to analyze the causal linkage between energy use and GDP using different methodologies. For instance, Dagher and Yacoubian (2012) put an effort to increase the robustness of the results by employing a variety of causality tests, namely Hsiao, Toda-Yamamoto, and vector error correction-based Granger causality tests using the data of Lebanon. They find strong evidence of a bidirectional relationship both in the

\footnotetext{
${ }^{1}$ For more information on panel data studies, see Huang et al. (2008), Al-Iriani (2006), and Lee (2006).
}

short run and in the long run, indicating that energy is a limiting factor to economic growth in Lebanon. The study developed by Lee (2006) explores whether energy conservation policies can be implemented in countries with the same level of development.

The results clearly do not support the view that energy consumption and income are neutral with respect to each other, except in the case of the UK, Germany, and Sweden where a neutral relationship is found, where the findings for the rest of countries are contrary. Ozturk (2010) has pointed that the inconsistent results in literature may vary not only due to the different data sets, countries' characteristics, and variables used, but different econometric methodologies employed for a single country may also yield distinct findings such that of Vaona (2012). In line, Apergis and Payne (2010c) highlight the importance of recognizing the heterogeneity in the behavior of petroleum consumption across a country states in the formulation of energy conservation and demand management policies. In addition, many studies use total energy/electricity consumption rather than disaggregated energy use information, which might increase the opportunity of having conflicting results as proposed by Sari and Soytas (2004).

Since there is growing scarcity of fossil resources and increasing world energy demand, Fiore (2006) suggest that transition from fossil fuels to renewable or other nongreenhouse gas-emitting energy sources would provide a long-term solution. In particular, nuclear power is undeniable asset, which can face new constraints and thus plays a vital role in the development of long-term energy and environmental strategies (Apergis and Payne 2010a). On the one hand, nuclear energy is very competitive and harmless to greenhouse effect. From this point, it seems to be an ideal candidate to reach future objectives of sustainability, availability, and acceptability.

In this respect, Menyah and Wolde-Rufael (2010) explores that renewable energy can help to mitigate $\mathrm{CO} 2$ emissions, but so far, renewable energy consumption has not reached a level where it can make a significant contribution to emissions reduction. Using panel data set, Yoo and $\mathrm{Ku}$ (2009) find that nuclear energy consumption and output are cointegrated in only six out of 20 countries. Thus, they attempt to investigate the causal relationship between nuclear energy consumption and economic growth for those countries, which results conflicting findings. ${ }^{2}$ Lee and Chiu (2011b) examine the short-run dynamics and long-run equilibrium relationships among nuclear energy consumption, oil prices, oil consumption, and economic growth for developed countries. The panel cointegration results show that in the long run, oil prices have a positive impact on nuclear energy consumption, suggesting the

\footnotetext{
${ }^{2}$ For more details, see Yoo and $\mathrm{Ku}$ (2009).
} 
existence of the substitution relationship between nuclear energy and oil. Nazlioglu et al. (2011) study the direction causality between nuclear energy consumption and economic growth in 14 OECD countries. They employ TodaYamamoto time series causality test and realize that the findings from the panel causality test are inconsistent with those obtained from the time series analysis. Therefore, it is concluded that the choice of statistical tools in analyzing the nature of causality between nuclear energy consumption and economic growth may play a key role for policy implications. Chu and Chang (2012) find that both nuclear and oil consumption play a considerable role in stimulating economic growth in G-6 countries. Jobert et al. (2013) find that nuclear energy goes from being a normal good to being an inferior good for the majority of his sample countries.

So far, most of studies that examine the linkage between nuclear energy consumption and economic growth use panel data. Yet, time series data may be more robust due to not only specific countries characteristics, but also because energy patters in a country might differ from time to another. Accordingly, accounting for countries individual characteristics require using time series data. In addition, the interaction between nuclear energy consumption and the fluctuations in oil market has paid lower attention in the literature (Lee and Chiu 2011a, b; Naser 2014, 2015a, b).

Hence, this paper attempts analyze the long-run relationship between nuclear energy consumption, oil consumption, oil prices, and economic growth by employing a parsimonious vector equilibrium correction model (PVECM). Causal linkage is also examined between the proposed variables.

\section{Material and method}

This study aims to analyze the long-run relationship between oil consumption, nuclear energy consumption, oil prices, and economic growth for selected developed countries. To do so, the maximum likelihood approach developed by Johansen and Juselius (1990) has been used. In this setup, all the number of distinct cointegration vectors between the variables in a multivariate setting are tested. Then, the parameters of these cointegration relationships are estimated, where the estimation is constructed on the basis of trace statistics and maximum eigenvalue tests. Johansen cointegration approach treats all variables as endogenous, which in terms avoiding any illogical choice of dependent variable. Moreover, this technique provides a unified framework for testing and estimating relationships within the framework of a vector error correction mode (VECM). As long as the variables included in the cointegration space have common trend, causality in the Granger sense must exist in at least one direction
(Granger 1988). Therefore, based on the multiple variables system used in this paper, we use the Johansen method (Johansen and Juselius 1990) to investigate the existence of long-run relationships between the variables.

\subsection{Stationarity test}

Stationary tests are first used for identifying the order of integration of each of the proposed variables. In the literature, the most popular approaches are the Augmented Dickey and Fuller (1979) (ADF), Phillips and Perron (1988) (PP), and Kwiatkowski et al. (1992) (KPSS). The three tests above are applied to identify the order of integration of each series, $I_{d}$. It is worth to note that the difference between the ADF, PP, and the KPSS tests is that the formulation of the null hypothesis, where the null hypothesis for both ADF and PP tests is non-stationary series and KPSS assumes that the series to be investigated is stationary. In this study, all these tests are utilized to verify the variables' order of integration, Id. The ADF [augmented (Dickey and Fuller 1979)] testing procedure to test the unit root hypothesis following:

$$
\Delta y_{t-1}=\theta_{0}+\gamma_{0} t+\gamma_{1} y_{t-1}+\sum_{i=0}^{p} \theta_{1} \Delta y_{t-1}+\varepsilon_{t}
$$

where $y_{t}$ is the variable in period t; $\Delta y_{t-1}$ is the $y_{t-1}-y_{t-2}$; $\varepsilon_{t}$ is the i.i.d. disturbance with mean 0 and variance $1 ; \mathrm{t}$ is the linear time trend; and $\mathrm{p}$ is the lag order. In order to test the null hypothesis for the presence of a unit root in $y_{t}$, we conducted the hypothesis testing that $\gamma_{1}=0$ in Eq. (1). If $\gamma_{1}=1$ is significantly less than zero, the null hypothesis of a unit root is rejected. The Phillips-Perron test uses similar models as the ADF tests, but lack of sensitivity to the heteroscedasticity and the autocorrelation of the residuals. Moreover, ADF tests and PP tests may be inefficient on small samples. KPSS stationarity test is more effective for small samples when it chooses a lower lag truncation parameter.

\subsection{Lag selection for VAR model}

To select the optimal number of lag length, $k$, this study uses Akaike (AIC), Hannan and Quinn (HQIC), and Schwarz's Bayesian (SIC) information criteria. ${ }^{3}$ Following Lütkepohl (1993) procedure, we link the maximum lag lengths $\left(k_{\max }\right)$ and the number of endogenous variables in the system $(m)$ to the sample size $(T)$ according to the formula $m \times k_{\max }=T^{1 / 3}$. In the case of conflicting results of

\footnotetext{
3 It is very important to choose the right optimal lag for cointegration analysis and causality testing as omitting relevant lags may bias the results.
} 
the different Information criterion, the choice done based on AIC results as suggested by Pesaran and Pesaran (1997).

\subsection{Johansen cointegration test}

Once all variables are integrated of the same order, a cointegration methodology that starts with a general approach and move to a more specific is applied to estimate the long-run relationship(s) between the variables included in vector $Z_{t}$, where $Z_{t}$ includes a number of integrated series at the same level. To do so, the long-run relationships between the variables included in vector $Z_{t}$ are estimated using Johansen Maximum Likelihood approach. Specifically, one can write $Z_{t}$ as a vector autoregressive process of order k (i.e., $\operatorname{VAR}(\mathrm{k}))$ :

$Z_{t}=A_{0}+\sum_{i=1}^{k} A_{i} Z_{t-i}+u_{t}$

$\Delta Z_{t}=A_{0}+\Pi Z_{t-1}+\sum_{i=1}^{k} \Gamma_{i} \Delta Z_{t-i}+u_{t}$

where $Z_{t}$ denotes $(4 \times 1)$ vector containing GDP, oil consumption, nuclear energy consumption, and real oil prices (i.e., $Z_{t}=\left(G D P_{t}, O C_{t}, N C_{t}, O P_{t}\right)$. The four variables are measured by their natural logarithm so that their first difference approximates their growth rates. Any long-run relationship(s) are captured by the $(4 \times 4)$ matrix $\Pi$ shown in Eq. (3). To examine the long-run relationship(s) between oil consumption, nuclear energy consumption, oil price and economic growth, Johansen (1988) test has been established in order to test for the existence of $r \leq 3$ cointegration relationships among the four variables of the model. This is equivalent to testing the hypothesis that the rank of matrix $\Pi$ in Eq. (3) is at most r. Reduced-rank regression can then be used to form a likelihood ratio test of that hypothesis on the basis of the so-called trace statistic, or alternatively, the maximum eigenvalue statistic. Lüutkepohl et al. (2001) investigate the small sample properties of both tests and conclude that the trace testis slightly superior, and therefore, we favor it in our analysis. Thus, the rank of the matrix . is imposed to estimate the unrestricted model shown in Eq. (3). However, this matrix (i.e., $\Pi$ ) can be decomposed as shown below in Eq. (4) to provide better understanding for the full system:

$$
\Delta Z_{t}=A_{0}+\alpha \beta^{\prime} Z_{t-1}+\sum_{i=1}^{p} \Gamma_{i} \Delta Z_{t-i}+u_{t}, \quad u_{t} \text { isiid } \sim \mathrm{N}(0, \Sigma)
$$

where the cointegrating vectors are presented in a $(4 \times r)$ matrix named $\beta$ and the speed of adjustments are shown in a $(4 \times r)$ matrix called $\alpha . \Gamma_{i}$ represents $(4 \times 4)$ matrices that guide short-run dynamics of the model.
Secondly, following Johansen (1996), we test for excluding all the proposed variables to identify the cointegrating relationship(s) by using zero restriction on $\beta$. Then, the model shown in Eq. (4) is re-estimated taken into consideration the identified matrix of cointegrating vectors $\beta$ as follow:

$$
\Delta Z_{t}=\hat{A}_{0}+\hat{\alpha}\left(\sum_{i=1}^{r} \hat{\beta}_{i}^{\prime} Z_{t-1}\right)+\sum_{i=1}^{p} \hat{\Gamma}_{i} \Delta Z_{t-i}+u_{t}
$$

At this point, we exclude any insignificant regressor and reestimate Eq. (5). The resulting parsimonious vector equilibrium correction model (PVECM) is a reduced form model and consequently, there are simultaneity effects among the endogenous variables including in $Z_{t} .{ }^{4}$ Given that the PVECM is estimated, the exogeneity test gives an indication about the causal relationship between the variables. This can be done by examining whether the null $\alpha_{i}$ is not significantly different from zero (i.e., $H_{0}: \alpha_{i}=0$ ). If we cannot reject the null, then the variable included; $z_{i}$ is exogenous with respect to all cointegrating vectors. Finally, the restricted PVECM is estimated as shown below in Eq. (5) under the condition of those exogenous indicators.

$$
\begin{aligned}
\Delta Z_{1, t}= & \hat{A}_{0}+\Delta Z_{2, t}+\hat{\alpha}\left(\sum_{i=1}^{r} \hat{\beta}_{i}^{\prime} Z_{t-1}\right) \\
& +\sum_{i=1}^{p} \hat{\Gamma}_{i} \Delta Z_{t-i}+u_{t}, \quad u_{t} \quad \text { is iid } \sim N\left(0, \Sigma_{1}\right)
\end{aligned}
$$

where $\hat{\alpha}=\left[\alpha_{1}, 0\right]^{\prime}$, and $Z_{2}$ is the vector of exogenous variables. Finally, simultaneous effects in Eq. (6) have been modeled. Once we find that there is insignificant diagonal element in $\Sigma_{1}$, OLS can be estimated for each equation of Eq. (6).

\subsection{Stability tests}

Testing whether the estimated long-run parameters do change over time is important because unstable parameters can result in model misspecification, which can potentially bias the results. Hence, for testing the long-run parameter stability in the cointegrating equations, where economic growth is the dependent variable, multivariate recursive procedures that proposed by Hansen and Johansen (1993, 1999) are employed to evaluate the constancy of both the cointegration space and the loadings of the cointegration vector. The constancy of cointegration space test is a recursive test, which compares the likelihood ratio test with that of the likelihood function from each subsample

\footnotetext{
${ }^{4}$ For more information on parsimonious vector error correction model (PVECM), see Arestis et al. (2002), among others.
} 
with the restriction that the cointegration vectors estimated from the full sample fall within the space spanned by the estimated long-run vectors. The test for the stability of the loading coefficients of the VECM is performed once the cointegration space has been uniquely identified, and allows one to test whether the responses of the variables to the long-run disequilibrium are stable over time.

\section{Data source and description}

The yearly data set used in this paper covers the period from 1965 to 2010 for four developed countries, including the USA, Canada, Japan, and France. The set of variables in this study are time series variables that include nuclear energy consumption per capita (NC), real oil prices (OP), oil consumption per capita (OC), and real GDP per capita (GDP). Oil consumption is the sum of inland demand, international aviation, marine bunkers, oil products consumed in the refining process, and consumption of fuel ethanol and biodiesel. Both nuclear energy and oil consumption are obtained from BP Statistical Review of World Energy (2011) where NC is expressed in terms of Terawatt-hours (TWh) and OC is measured in thousand barrels daily. Oil consumption (OC) is the sum of inland demand, international aviation, marine bunkers, oil products consumed in the refining process, and consumption of fuel ethanol and biodiesel. Real GDP per capita measured based on purchasing-power-parity (PPP) per capita in constant 2000 international dollars from the World Development Indicators (WDI 2011). Real oil price is defined as the US dollar prices of oil converted to the domestic currency and then deflated by the domestic consumer price index (CPI), which is derived from International Financial Statistics (IFS 2009) published by the International Monetary Fund (IMF). All data are expressed in natural logarithms in the empirical analysis as shown in Fig. 1. The empirical investigation started by
USA

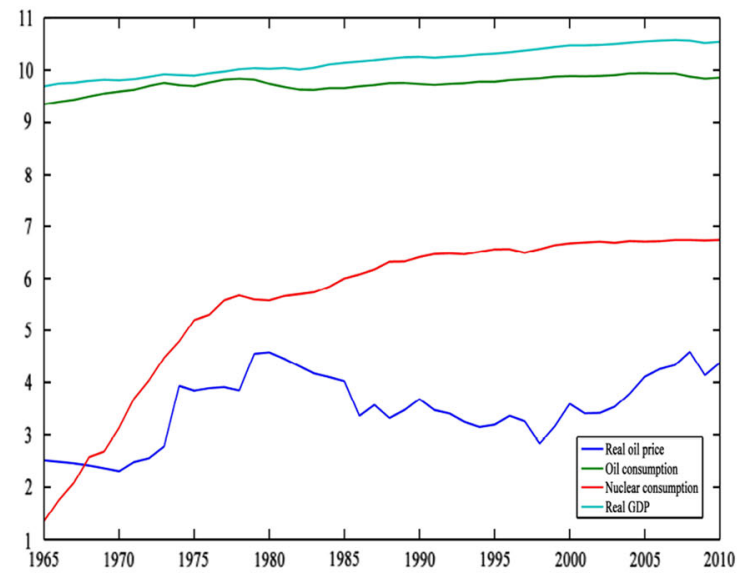

France

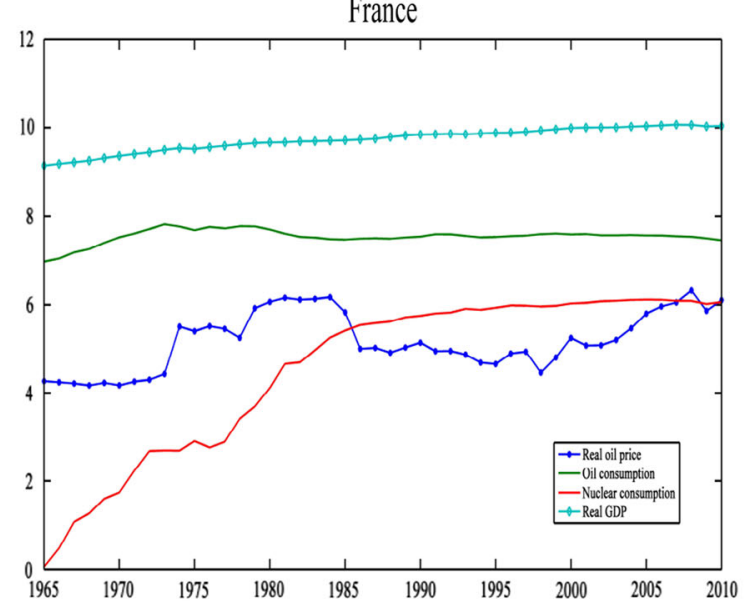

Canada

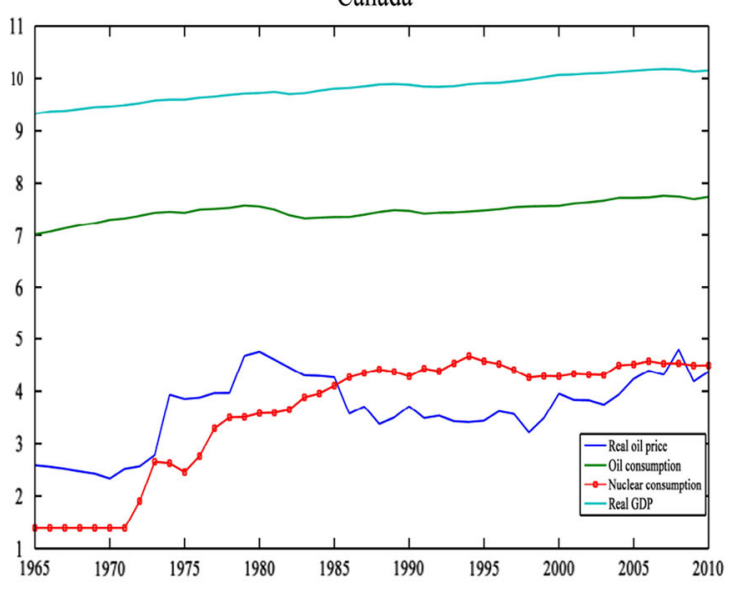

Fig. 1 Country data. Note the figure represents the country level data of each tested country including: the USA, Canada, Japan and France. The plotted series are real GDP, oil consumption, oil price, and nuclear energy consumption 
Table 1 Descriptive statistics

\begin{tabular}{|c|c|c|c|c|}
\hline Country & USA & Canada & Japan & France \\
\hline \multicolumn{5}{|c|}{ Real oil price } \\
\hline Mean & 3.52 & 3.66 & 8.44 & 5.18 \\
\hline SD & 0.67 & 0.68 & 0.27 & 0.66 \\
\hline Skewness & -0.24 & -0.41 & -2.35 & 0.07 \\
\hline Kurtosis & 2.06 & 2.31 & 8.15 & 1.85 \\
\hline Normality & 2.04 & 2.16 & 4.34 & 2.57 \\
\hline$p$ value & $(0.36)$ & $(0.34)$ & $(0.11)$ & $(0.28)$ \\
\hline \multicolumn{5}{|c|}{ Oil consumption } \\
\hline Mean & 9.75 & 7.47 & 8.44 & 7.55 \\
\hline SD & 0.14 & 0.17 & 0.27 & 0.17 \\
\hline Skewness & -0.91 & -0.49 & -2.35 & -1.49 \\
\hline Kurtosis & 3.63 & 3.21 & 8.15 & 6.32 \\
\hline Normality & 4.21 & 2.25 & 111.79 & 1.31 \\
\hline$p$ value & $(0.11)$ & $(0.33)$ & $(0.00)$ & (0.09) \\
\hline \multicolumn{5}{|c|}{ Nuclear energy consumption } \\
\hline Mean & 5.57 & 3.60 & 4.14 & 4.56 \\
\hline SD & 1.50 & 1.45 & 2.21 & 1.84 \\
\hline Skewness & -1.50 & -1.05 & -1.71 & -0.95 \\
\hline Kurtosis & 4.10 & 2.58 & 5.33 & 2.53 \\
\hline Normality & 22.03 & 9.32 & 38.39 & 7.72 \\
\hline$p$ value & $(0.08)$ & $(0.01)$ & $(0.00)$ & $(0.02)$ \\
\hline \multicolumn{5}{|l|}{ Real GDP } \\
\hline Mean & 10.17 & 9.81 & 10.21 & 9.73 \\
\hline SD & 0.27 & 0.24 & 0.35 & 0.26 \\
\hline Skewness & -0.09 & -0.22 & -0.79 & -0.61 \\
\hline Kurtosis & 1.75 & 2.07 & 2.66 & 2.41 \\
\hline Normality & 3.10 & 1.96 & 5.20 & 3.59 \\
\hline$p$ value & $(0.21)$ & (0.38) & $(0.07)$ & $(0.17)$ \\
\hline
\end{tabular}

summarizing the descriptive statistics for the proposed variables across all countries as shown in Table 1 . The descriptive statistics are calculated to find the mean, standard deviation, minimum, maximum, skewness, kurtosis, and Jarque-Bera statistic for normality for each variable included in the analysis. With a glance at the results shown in Table 1, it is clear that the highest mean real GDP is observed in Japan followed by the USA, Canada, and France during the sample period (1965-2010). The USA has the mean highest oil consumption and nuclear energy consumption among the other countries. Majority of variables have negative skewness values, which denote that the distribution of the data is skewed to the left. However, results obtained from Jarque-Bera test show that real oil price, oil consumption, and real GDP exhibit normal distribution, while nuclear energy consumption seems to be characterized by a nonnormal distribution.

\section{Empirical results}

\subsection{Results of stationarity tests}

On the basis of the ADF and PP unit root tests, results shown in Table 2 reveal that all tested variables are nonstationary at level, which implies that we cannot reject the null hypothesis of non-stationarity. However, the stationarity property is reached after first differencing the variables. Although the results reported in Table 2 are slightly contradictory at levels, all variables are roughly integrated of order one (i.e. I(1)) after differencing.

\subsection{Results of lag selection tests}

Table 3 shows the results of lag selection criteria for each country using Akaike (AIC), Hannan and Quinn (HQIC), and Schwarz's Bayesian (SIC) information criteria as discussed above. If the optimal lags on the basis different tests are conflicting, the optimal number of lag length, $\mathrm{k}$, is selected on the basis of AIC as suggested by Pesaran and Pesaran (1997).

For further investigations, diagnostic tests including normality and autocorrelation have been employed. Based on Lagrange multiplier (LM) test for autocorrelation shown in Table 4, the null hypothesis of no autocorrelation in the residuals cannot be rejected for any of the orders tested at $5 \%$ level. Also, all models pass the normality test at $10 \%$ level or better, which indicate that there is no evidence of model misspecification in our models.

\subsection{Results of johansen cointegration analysis}

Results of testing the number of cointegrating vectors are reported in Table 5, which presents both the maximum eigenvalue $\left(\lambda_{\max }\right)$ and the trace statistics. Results of trace statics in the fifth column of Table 5 show that the null hypothesis of no cointegration can be rejected at 1 and 5\% significance level, except for Canada. ${ }^{5}$ These findings suggest the existence of one cointegration vector in each country model. Hence, a cointegration rank of one is imposed on the VAR and the coefficients are estimated using Eq. (4) shown in Table 6.

However, from the $\beta$ vectors presented in Table 6 , it is clear that there are some insignificant coefficients of different variables in the cointegration space of each country model. Accordingly, following Johansen (1996), an exclusion test that examine whether or not a variable can be excluded from a cointegration space is utilized for all variables in each country model. Particularly, this test uses

\footnotetext{
5 In Canada, we reject the null hypothesis of no cointegration at $10 \%$ level.
} 
Table 2 Tests of unit root

\begin{tabular}{|c|c|c|c|c|c|c|c|}
\hline Country & Variable & $\mathrm{ADF}$ & Lags & PP (4) & PP (8) & KPSS & Lags \\
\hline \multicolumn{8}{|l|}{ US } \\
\hline \multirow[t]{4}{*}{ Levels } & $\mathrm{OP}$ & -1.698 & $(0)$ & -1.854 & -1.962 & 0.129 & (4) \\
\hline & OC & -3.344 & (1) & -2.746 & -2.720 & 0.086 & (4) \\
\hline & $\mathrm{NC}$ & -3.451 & (1) & $-3.748 *$ & $-4.339 * *$ & $0.230 * *$ & (4) \\
\hline & GDP & -3.203 & (1) & -2.098 & -1.820 & 0.098 & (4) \\
\hline \multirow[t]{4}{*}{ First difference } & $\mathrm{OP}$ & $-6.566^{* *}$ & $(0)$ & $-6.802 * *$ & $-6.808 * *$ & 0.109 & (4) \\
\hline & $\mathrm{OC}$ & $-4.165^{*}$ & (1) & $-3.606^{*}$ & -3.846 & 0.104 & (4) \\
\hline & $\mathrm{NC}$ & $-4.340 * *$ & $(0)$ & $-4.742 * *$ & $-4.847 * *$ & 0.163 & (4) \\
\hline & GDP & $-5.195 * *$ & (1) & $-5.602 * *$ & $-5.721 * *$ & 0.081 & (4) \\
\hline \multicolumn{8}{|l|}{ Canada } \\
\hline \multirow[t]{4}{*}{ Levels } & $\mathrm{OP}$ & -1.843 & $(0)$ & -1.948 & -2.052 & 0.130 & (4) \\
\hline & $\mathrm{OC}$ & -2.782 & (1) & -2.659 & -2.666 & 0.104 & (4) \\
\hline & $\mathrm{NC}$ & -0.712 & (0) & -0.743 & -0.684 & $0.247 * *$ & (4) \\
\hline & GDP & -2.476 & (1) & -2.261 & -2.032 & 0.127 & (4) \\
\hline \multirow[t]{4}{*}{ First difference } & $\mathrm{OP}$ & $-7.113 * *$ & $(0)$ & $-5.461 * *$ & $-5.922 * *$ & 0.096 & (4) \\
\hline & $\mathrm{OC}$ & $-3.752 *$ & $(0)$ & -0.630 & -0.359 & 0.128 & (4) \\
\hline & $\mathrm{NC}$ & $-6.276^{* *}$ & (1) & -1.953 & -1.791 & 0.082 & (4) \\
\hline & GDP & $-5.012 * *$ & $(0)$ & -0.935 & -0.831 & 0.066 & (4) \\
\hline \multicolumn{8}{|l|}{ Japan } \\
\hline \multirow[t]{4}{*}{ Levels } & OP & -1.809 & $(0)$ & -1.926 & -2.066 & 0.116 & (4) \\
\hline & $\mathrm{OC}$ & -2.153 & (6) & $-4.108^{*}$ & $-3.979 *$ & $0.159 *$ & (4) \\
\hline & $\mathrm{NC}$ & -3.156 & (7) & $-6.627 *$ & $-6.385^{* *}$ & $0.247 * *$ & (4) \\
\hline & GDP & -3.257 & $(0)$ & -3.149 & -3.165 & $0.243 * *$ & (4) \\
\hline \multirow[t]{4}{*}{ First difference } & $\mathrm{OP}$ & $-6.188 * *$ & $(0)$ & $-6.444 * *$ & $-6.422 * *$ & 0.100 & (4) \\
\hline & OC & $-3.707 *$ & $(0)$ & $-3.774 *$ & $-3.88 *$ & 0.137 & (4) \\
\hline & $\mathrm{NC}$ & $-4.742 * *$ & (4) & $-12.75 * *$ & $-12.96 * *$ & 0.20 & (4) \\
\hline & $\mathrm{Y}$ & $-4.566^{* *}$ & (1) & $-4.482 * *$ & $-4.369 * *$ & 0.0925 & (4) \\
\hline \multicolumn{8}{|l|}{ France } \\
\hline \multirow[t]{4}{*}{ Levels } & $\mathrm{OP}$ & -1.654 & (0) & -1.835 & -1.936 & $0.158^{*}$ & (4) \\
\hline & $\mathrm{OC}$ & $-3.999 *$ & (1) & $-3.592^{*}$ & $-3.545^{*}$ & 0.124 & (4) \\
\hline & $\mathrm{NC}$ & -1.548 & $(0)$ & -1.563 & -1.592 & 0.114 & (4) \\
\hline & GDP & -2.110 & (1) & -2.009 & -2.114 & $0.261 * *$ & (4) \\
\hline \multirow[t]{4}{*}{ First difference } & $\mathrm{OP}$ & $-6.297 * *$ & $(0)$ & $-6.522 * *$ & $-6.528 * *$ & 0.108 & (4) \\
\hline & $\mathrm{OC}$ & $-3.733^{*}$ & $(0)$ & $-3.899 *$ & $-3.984 *$ & 0.141 & (4) \\
\hline & $\mathrm{NC}$ & $-1.974^{*}$ & (2) & $-5.741 * *$ & $-5.672 * *$ & 0.059 & (4) \\
\hline & GDP & $-4.990 * *$ & $(0)$ & $-5.105^{* *}$ & $-5.031 * *$ & 0.093 & (4) \\
\hline
\end{tabular}

Table entries are the results obtained from unit root tests. Tests are shown in the first row: augmented Dickey and Fuller (1979) (ADF), Phillips and Perron (1988) (PP), and the stationarity test by Kwiatkowski et al. (1992) (KPSS). Regression includes an intercept and trend. The variables are specified in the first column: oil price (OP), oil consumption (OC), nuclear energy consumption (NC), and real GDP (Y). All variables are in natural logarithms, while the lag length determined by Akaike Information Criteria and are in parentheses. '*' and '**' indicate significance at the 10 and 5\% level, respectively. The nulls for all test except for the KPSS test are unit root

zero restriction on $\beta$ to identify the long-run relationship. Results provided in Table 7 shown below reveal that the USA exclusion tests of nuclear energy consumption and real oil price yield likelihood ratio test of 0.943 and 0.084 , respectively. This enables us to easily accept the null hypothesis and therefore exclude these two variables from the USA cointegration space. Following the same method, nuclear energy consumption is excluded from the cointegrating vector of Canada as the statistics show a likelihood ratio of 0.276 . In Japan, findings support that the cointegration vector is clearly identified by excluding both oil consumption and real oil price. Results of likelihood ratio test for France provided in the third column of Table 7 report that the null hypothesis of $H_{0}: \beta=0$ is rejected for 
Table 3 Lag selection criteria

\begin{tabular}{lllll}
\hline Country & K & AIC & HQIC & SBIC \\
\hline USA & 1 & $-11.6764^{*}$ & $-11.3731^{*}$ & $-10.849^{*}$ \\
& 2 & -11.665 & -11.119 & -10.176 \\
& 3 & -11.673 & -10.884 & -9.522 \\
& 4 & -11.612 & -10.581 & -8.799 \\
Canada & 1 & -9.819 & $-9.515^{*}$ & $-8.991^{*}$ \\
& 2 & -9.655 & -9.109 & -8.166 \\
& 3 & $-9.889^{*}$ & -9.101 & -7.738 \\
& 4 & -9.851 & -8.820 & -7.038 \\
Japan & 1 & -8.635 & -8.332 & $-7.808^{*}$ \\
& 2 & -8.286 & -7.740 & -6.796 \\
& 3 & -8.313 & -7.525 & -6.162 \\
France & 1 & $-10.757^{*}$ & $-10.453^{*}$ & -6.722 \\
& 2 & -10.499 & -9.953 & -9.010 \\
& 3 & -10.344 & -9.555 & -8.193 \\
& 4 & -10.721 & -9.690 & -7.908
\end{tabular}

AIC, HQIC, and SBIC stand for Akaike, Hannan and Quinn, and Schwarz's Bayesian information criteria, respectively. In the case of conflicting results, we use AIC results as suggested by Pesaran and Pesaran (1997). ' $*$ ' indicates significant at 5\% level

Table 4 Multivariate misspecification tests

\begin{tabular}{lll}
\hline Country & Test & Test statistics \\
\hline USA & LM (1) & $\chi^{2}(16)=17.185(0.374)$ \\
& LM (2) & $\chi^{2}(16)=14.543(0.558)$ \\
& Normality & $\chi^{2}(8)=13.216(0.105)$ \\
Canada & LM (1) & $\chi^{2}(16)=17.185(0.374)$ \\
& LM (2) & $\chi^{2}(16)=16.449(0.422)$ \\
Japan & Normality & $\chi^{2}(8)=4.690(0.790)$ \\
& LM (1) & $\chi^{2}(16)=17.185(0.374)$ \\
& LM (2) & $\chi^{2}(16)=22.756(0.120)$ \\
France & Normality & $\chi^{2}(8)=14.046(0.081)$ \\
& LM (1) & $\chi^{2}(16)=17.185(0.374)$ \\
& LM (2) & $\chi^{2}(16)=22.149(0.138)$ \\
& Normality & $\chi^{2}(8)=11.790(0.161)$ \\
\hline
\end{tabular}

$p$ values are given in parentheses. Lagrange multiplier (LM): $H_{0}$ : No autocorrelation at lag order. Normality: $H_{0}$ : Disturbances are normally distributed

all the proposed variables, except for real oil price, which denotes that real GDP, oil and nuclear energy consumption determine the long-run linkage significantly.

After excluding the insignificant variables from the cointegration space, weak exogeneity is investigated against the null hypothesis $H_{0}: \alpha=0$, as proposed by Johansen $(1992,1996)$. A rejection of the null hypothesis means that there is evidence of unidirectional long-run causality (Arestis et al. 2001). With a glance at the results
Table 5 Johansen's cointegration test

\begin{tabular}{llllrll}
\hline Country & $H_{0}$ & $H_{1}$ & $\lambda_{\max }$ & Trace* $^{*}$ & $95 \%$ c.v & $p$ value* \\
\hline USA & $r=0$ & 4 & 0.783 & 76.347 & 63.659 & $0.002^{* * *}$ \\
& $r \leq 1$ & 3 & 0.495 & 34.703 & 42.770 & 0.261 \\
& $r \leq 2$ & 2 & 0.396 & 20.706 & 25.731 & 0.195 \\
Canada & $r=0$ & 1 & 0.216 & 6.987 & 12.448 & 0.356 \\
& $r \leq 1$ & 3 & 0.596 & 51.751 & 53.945 & $0.079 *$ \\
& $r \leq 2$ & 2 & 0.295 & 7.614 & 20.164 & 0.850 \\
Japan & $r \leq 3$ & 1 & 0.078 & 1.796 & 9.142 & 0.811 \\
& $r=0$ & 4 & 0.572 & 68.773 & 63.659 & $0.017 * *$ \\
& $r \leq 1$ & 3 & 0.465 & 39.232 & 42.770 & 0.111 \\
& $r \leq 2$ & 2 & 0.365 & 19.752 & 25.731 & 0.243 \\
France & $r \leq 3$ & 1 & 0.250 & 7.554 & 12.448 & 0.299 \\
& $r=0$ & 4 & 0.455 & 68.158 & 63.659 & $0.048 * *$ \\
& $r \leq 1$ & 3 & 0.398 & 27.715 & 42.770 & 0.643 \\
& $r \leq 2$ & 2 & 0.281 & 17.022 & 25.731 & 0.421 \\
& $r \leq 3$ & 1 & 0.207 & 7.649 & 12.448 & 0.290 \\
\hline
\end{tabular}

The entries of the upper row show the name of the country in the first column, followed by the null hypothesis $H_{0}$, that tests for a cointegration rank of $r$, then $H_{1}$ shows the alternative. $\lambda_{\max }$ shown in the fourth column represents the maximum eigenvalue statistics, Trace* shows the trace statics, $95 \%$ c.v represents the critical values at $5 \%$ level, and finally $p$ values are provided in the last column. '*', '**', and '***' indicate significance at the 10,5 , and $1 \%$ level, respectively

reported in Table 8, it is clear that oil consumption is exogenous in three out of four countries including the USA, Japan, and France, with test statistics of $0.361,0.366$, and 0.248 , respectively. This implies that oil consumption has a predictive power to economic growth in these countries, which is in line with Lee and Chiu (2011a) outcomes for France, the UK, and the USA. However, it is contradicting with Lee and Chiu (2011b) results, who use panel data set in their analysis. They find that there is an opposite causality running from real income to oil consumption in the short run, implying that an increase in real income may lead to the demands for oil in the short run and that the policies for reducing oil consumption may not retard economic growth. On the other hand, nuclear energy consumption cannot reject the null hypothesis of weak exogeneity in both the USA and Canada, with likelihood ratios of 3.155 and 0.692 , respectively, suggesting a unidirectional causal linkage running from nuclear energy consumption to economic growth. Thus, a high level of nuclear power consumption leads to high level of real economic growth in the USA and Canada. These results support the findings of the long-run causality from nuclear energy consumption to economic growth for Korea by Yoo and Jung (2005) and Yoo and Ku (2009), Wolde-Rufael and Menyah (2010) for Japan, Apergis and Payne (2010b) for panel data of 16 countries, and Wolde-Rufael (2010). 
Table 6 Un-restricted long-run relationship using Johansen's cointegration technique

\begin{tabular}{|c|c|c|c|c|}
\hline Country & $\beta_{1}$ & & $\alpha_{1}$ & \\
\hline \multirow[t]{4}{*}{ USA } & $\mathrm{OC}$ & $\begin{array}{l}-0.786 * * * \\
(-5.200)\end{array}$ & $\Delta \mathrm{GDP}$ & $\begin{array}{l}-0.224 * * * \\
(-3.745)\end{array}$ \\
\hline & $\mathrm{NC}$ & $\begin{array}{l}-0.015 \\
(-1.203)\end{array}$ & $\Delta \mathrm{OC}$ & $\begin{array}{l}0.060 \\
(0.679)\end{array}$ \\
\hline & $\mathrm{OP}$ & $\begin{array}{l}0.007 \\
(0.380)\end{array}$ & $\Delta \mathrm{NC}$ & $\begin{array}{l}0.704 * * \\
(2.026)\end{array}$ \\
\hline & $\mathrm{T}$ & $\begin{array}{l}-0.012 * * * \\
(-8.882)\end{array}$ & $\Delta \mathrm{OP}$ & $\begin{array}{l}-2.998 * * * \\
(-2.969)\end{array}$ \\
\hline \multirow[t]{4}{*}{ Canada } & $\mathrm{OC}$ & $\begin{array}{l}-2.433 * * * \\
(-12.012)\end{array}$ & $\Delta \mathrm{GDP}$ & $\begin{array}{l}-0.092 * * * \\
(-3.144)\end{array}$ \\
\hline & $\mathrm{NC}$ & $\begin{array}{l}-0.023 \\
(-1.035)\end{array}$ & $\Delta \mathrm{OC}$ & $\begin{array}{l}-0.065 \\
(-1.442)\end{array}$ \\
\hline & OP & $\begin{array}{l}0.357 * * * \\
(7.621)\end{array}$ & $\Delta \mathrm{NC}$ & $\begin{array}{l}-0.288 \\
(-1.084)\end{array}$ \\
\hline & $\mathrm{C}$ & $\begin{array}{l}7.091 * * * \\
(5.222)\end{array}$ & $\Delta \mathrm{OP}$ & $\begin{array}{l}-1.766^{* * *} \\
(-5.620)\end{array}$ \\
\hline \multirow[t]{4}{*}{ Japan } & $\mathrm{OC}$ & $\begin{array}{l}0.101 \\
(1.427)\end{array}$ & $\Delta \mathrm{GDP}$ & $\begin{array}{l}-0.261 * * * \\
(-3.638)\end{array}$ \\
\hline & $\mathrm{NC}$ & $\begin{array}{l}-0.123 * * * \\
(-10.413)\end{array}$ & $\Delta \mathrm{OC}$ & $\begin{array}{l}0.156 \\
(1.158)\end{array}$ \\
\hline & OP & $\begin{array}{l}0.009 \\
(0.592)\end{array}$ & $\Delta \mathrm{NC}$ & $\begin{array}{l}2.510 * * * \\
(3.451)\end{array}$ \\
\hline & $\mathrm{T}$ & $\begin{array}{l}-0.011 * * * \\
(-9.351)\end{array}$ & $\Delta \mathrm{OP}$ & $\begin{array}{l}0.024 \\
(0.022)\end{array}$ \\
\hline \multirow[t]{4}{*}{ France } & $\mathrm{OC}$ & $\begin{array}{l}-0.249 * * * \\
(-7.656)\end{array}$ & $\Delta \mathrm{GDP}$ & $\begin{array}{l}-0.238 * * * \\
(-2.588)\end{array}$ \\
\hline & $\mathrm{NC}$ & $\begin{array}{l}-0.039 * * * \\
(-5.402)\end{array}$ & $\Delta \mathrm{OC}$ & $\begin{array}{l}-0.279 \\
(-0.987)\end{array}$ \\
\hline & $\mathrm{OP}$ & $\begin{array}{l}0.038 * * * \\
(3.898)\end{array}$ & $\Delta \mathrm{NC}$ & $\begin{array}{l}3.382 * * * \\
(4.295)\end{array}$ \\
\hline & $\mathrm{T}$ & $\begin{array}{l}-0.015 * * * \\
(-15.891)\end{array}$ & $\Delta \mathrm{OP}$ & $\begin{array}{l}-4.847 * * * \\
(-2.438)\end{array}$ \\
\hline
\end{tabular}

Table entries are the estimates of the un-restricted long-run relationship using Johansen's cointegration technique. The long-run relationship has been normalized on the economic growth (GDP). The variables in the first column are: oil consumption (OC), nuclear energy consumption (NC), and real oil price $(\mathrm{OP}) . \beta_{1}$ represents the estimated long-run parameters and $\alpha_{1}$ shows the speed of adjustment in each equation. Numbers in parentheses are t-statistics where $* * *$, $* *$, and $*$ denote significance at the 1,5 , and $10 \%$, respectively

Yet, it is conflicting with Yoo and $\mathrm{Ku}$ (2009) for France and Pakistan, and Wolde-Rufael (2010) for Canada and Switzerland. ${ }^{6}$ With respect to oil price exogeneity test, Table 8 indicates that there is a unidirectional causal

\footnotetext{
${ }^{6}$ Payne and Taylor (2010) also find different results as they show that there is no causal relationship between nuclear energy consumption and economic growth in the USA.
}

Table 7 Variables exclusion test

\begin{tabular}{|c|c|c|c|}
\hline Country & Variable & LR test & $p$ value \\
\hline \multirow[t]{5}{*}{ USA } & GDP & $3.824 * *$ & 0.050 \\
\hline & OC & $10.136 * * *$ & 0.001 \\
\hline & $\mathrm{NC}$ & 0.943 & 0.332 \\
\hline & OP & 0.084 & 0.772 \\
\hline & $\mathrm{T}$ & $1.537 * *$ & 0.025 \\
\hline \multirow[t]{5}{*}{ Canada } & GDP & $5.157 * *$ & 0.023 \\
\hline & $\mathrm{OC}$ & $11.946 * * *$ & 0.001 \\
\hline & $\mathrm{NC}$ & 0.276 & 0.599 \\
\hline & $\mathrm{OP}$ & $12.184 * * *$ & 0.000 \\
\hline & $\mathrm{C}$ & $9.485 * * *$ & 0.002 \\
\hline \multirow[t]{5}{*}{ Japan } & GDP & $6.729 * * *$ & 0.009 \\
\hline & $\mathrm{OC}$ & 0.457 & 0.499 \\
\hline & $\mathrm{NC}$ & $6.790 * * *$ & 0.009 \\
\hline & $\mathrm{OP}$ & 0.072 & 0.788 \\
\hline & $\mathrm{T}$ & $4.931 * *$ & 0.026 \\
\hline \multirow[t]{5}{*}{ France } & GDP & $11.108 * * *$ & 0.001 \\
\hline & $\mathrm{OC}$ & $6.070 * *$ & 0.014 \\
\hline & $\mathrm{NC}$ & $8.093 * * *$ & 0.004 \\
\hline & ROP & 0.754 & 0.385 \\
\hline & $\mathrm{T}$ & $7.265 * * *$ & 0.007 \\
\hline
\end{tabular}

Table entries in the second column show the name of the variable tested for exclusion from the cointegration relationship including economic growth (GDP), oil consumption (OC), nuclear energy consumption (NC), and real oil price (OP). Tests are on the null hypothesis that the particular variable listed is not in the cointegration space. The test is constructed by re-estimating VECM model which cointegration coefficient $\beta$ in Eq. (4) for corresponding variable is restricted to zero. Under the null hypothesis, the test statistics is distributed Chi-squared with one degree o freedom. '***', '**', and '*' relate to the decision to reject the null hypothesis at 1,5 , and $10 \%$ significant level, respectively

relationship from real oil price to economic growth in both Japan and France.

Then, the model is re-estimated at this point using the parsimonious vector equilibrium correction model (PVECM) shown in Eq. (5). The results of $\beta$ and $\alpha$ estimates are based on the above exclusion and weak exogeneity restrictions for the investigated countries. Since all variables are in natural logarithms, the estimated long-run coefficients can be interpreted as elasticities. In the USA, it is observed that the long-run oil consumption elasticity of economic growth is 0.759 , which is positive and statistically significant at $1 \%$ level. This suggests that increasing oil consumption by $1 \%$, increases the real GDP growth by $0.759 \%$ in the USA. The coefficient on the time trend component can be interpreted as a measuring for the rate of technical change in the USA. The estimated rate of technical change is $0.12 \%$, which is close to that estimated by Stern (2000). In the case of Canada, it can be seen from the estimated long-run relationship that oil consumption has a 
Table 8 Variables exogeneity test

\begin{tabular}{llll}
\hline Country & Variable & LR test & $p$ value \\
\hline USA & GDP & $8.094^{*}$ & 0.004 \\
& OC & 0.361 & 0.548 \\
& NC & 3.155 & 0.076 \\
Canada & OP & $4.366^{*}$ & 0.037 \\
& GDP & $5.154^{*}$ & 0.023 \\
& OC & $1.424^{*}$ & 0.033 \\
Japan & NC & 0.692 & 0.406 \\
& OP & $10.091^{*}$ & 0.001 \\
& GDP & $4.060^{*}$ & 0.044 \\
& OC & 0.366 & 0.545 \\
France & NC & $5.970^{*}$ & 0.015 \\
& OP & 0.000 & 0.987 \\
& GDP & $3.903^{*}$ & 0.048 \\
& OC & 0.248 & 0.618 \\
& NC & $3.708^{*}$ & 0.054 \\
& OP & 1.170 & 0.279
\end{tabular}

Table entries in the second column show the name of the variable tested for weak exogeneity including economic growth (GDP), oil consumption $(\mathrm{OC})$, nuclear energy consumption (NC), and real oil price (OP). Tests are on the null hypothesis that the particular variable listed is not responsive to deviation from previous period cointegration relationship. That is the variable's speed of adjustment $\alpha$ in Eq. (5) is zero. Under the null hypothesis, the test statistics are distributed Chi-squared with one degree o freedom. '***', '**', and '*' relate to the decision to reject the null hypothesis at 1,5 , and $10 \%$ significant level, respectively.

positive and high significant impact on economic growth, while output is negatively linked with oil price. $^{7}$ An increase of $1 \%$ in oil consumption increases the growth by $3.1 \%$ approximately. In contrast, increasing oil price by $1 \%$ decreases the growth in Canada by $0.499 \%$.

Alternatively, the long-run nuclear energy consumption elasticity to economic growth in Japan shows that an increase of $1 \%$ in nuclear energy consumption increases the real GDP by $0.108 \% .^{8}$ Lee and Chiu (2011a) find that nuclear energy demand is elastic with respect to real income in Japan, and a $1 \%$ rise in real income raises nuclear energy consumption with a $1.436 \%$. They suggest that countries with higher-income levels are more likely to have their basic needs and are concerned with environmental problems, since they have more money to invest in nuclear energy development. Thus, for highly

\footnotetext{
7 Canada's economy is relatively energy-intensive when compared to other industrialized countries and is largely fueled by petroleum, which represents the highest primary energy consumption, while nuclear energy usage is much less, with about 32 and $7 \%$, respectively, from the total energy consumption (EIA 2012).

${ }^{8}$ One of the reasons for the shrinking of Japanese oil consumption during the period 1979-1985 was the construction of several nuclear power plants for electricity generation. This led to the substitution of crude and fuel oil and caused a drop in demand of around $1.2 \mathrm{mb} / \mathrm{d}$ for the whole period (OPEC's World Oil Outlook 2012).
}

Table 9 Restricted long-run relationship using Johansen's cointegration technique

\begin{tabular}{|c|c|c|c|c|}
\hline Country & $\beta_{1}$ & & $\alpha_{1}$ & \\
\hline \multirow[t]{4}{*}{ USA } & $\mathrm{OC}$ & $\begin{array}{l}-0.759 * * * \\
(-6.255)\end{array}$ & $\Delta \mathrm{GDP}$ & $\begin{array}{l}-0.283^{* * *} \\
(-4.770)\end{array}$ \\
\hline & $\mathrm{NC}$ & $\begin{array}{l}0.000 \\
(0.000)\end{array}$ & $\Delta \mathrm{OC}$ & $\begin{array}{l}0.000 \\
(0.000)\end{array}$ \\
\hline & OP & $\begin{array}{l}0.000 \\
(0.000)\end{array}$ & $\Delta \mathrm{NC}$ & $\begin{array}{l}0.000 \\
(0.000)\end{array}$ \\
\hline & $\mathrm{T}$ & $\begin{array}{l}-0.012 * * * \\
(-9.187)\end{array}$ & $\Delta \mathrm{OP}$ & $\begin{array}{l}-2.238 * * \\
(-1.992)\end{array}$ \\
\hline \multirow[t]{4}{*}{ Canada } & $\mathrm{OC}$ & $\begin{array}{l}-3.078 * * * \\
(-13.568)\end{array}$ & $\Delta \mathrm{GDP}$ & $\begin{array}{l}-0.053 * * \\
(-2.433)\end{array}$ \\
\hline & $\mathrm{NC}$ & 0.000 & $\Delta \mathrm{OC}$ & $\begin{array}{l}-0.053 * \\
(-1.652)\end{array}$ \\
\hline & OP & $\begin{array}{l}0.499 * * * \\
(7.501)\end{array}$ & $\Delta \mathrm{NC}$ & 0.000 \\
\hline & $\mathrm{C}$ & $\begin{array}{l}11.319 * * * \\
(7.494)\end{array}$ & $\Delta \mathrm{OP}$ & $\begin{array}{l}-1.355^{* * *} \\
(-6.341)\end{array}$ \\
\hline \multirow[t]{4}{*}{ France } & $\mathrm{OC}$ & $\begin{array}{l}-0.262 * * * \\
(-6.183)\end{array}$ & $\Delta \mathrm{GDP}$ & $\begin{array}{l}-0.320 \text { *** } \\
(-2.862)\end{array}$ \\
\hline & $\mathrm{NC}$ & $\begin{array}{l}-0.049 * * * \\
(-5.363)\end{array}$ & $\Delta \mathrm{OC}$ & 0.000 \\
\hline & OP & 0.000 & $\Delta \mathrm{NC}$ & 0.000 \\
\hline & $\mathrm{T}$ & $\begin{array}{l}-0.011 * * * \\
(-9.452)\end{array}$ & $\Delta \mathrm{OP}$ & 0.000 \\
\hline \multirow[t]{4}{*}{ Japan } & $\mathrm{OC}$ & 0.000 & $\Delta \mathrm{GDP}$ & $\begin{array}{l}-0.353 * * * \\
(-4.823)\end{array}$ \\
\hline & $\mathrm{NC}$ & $\begin{array}{l}-0.108 * * * \\
(-13.265)\end{array}$ & $\Delta \mathrm{OC}$ & 0.000 \\
\hline & OP & 0.000 & $\Delta \mathrm{NC}$ & $\begin{array}{l}2.662 * * * \\
(3.289)\end{array}$ \\
\hline & $\mathrm{T}$ & $\begin{array}{l}-0.012 * * * \\
(-12.701)\end{array}$ & $\Delta \mathrm{OP}$ & 0.000 \\
\hline
\end{tabular}

Table entries are the estimates of the un-restricted long-run relationship using Johansen's cointegration technique. The long-run relationship has been normalized on the economic growth (GDP). The variables in the first column are: oil consumption (OC), nuclear energy consumption (NC), and real oil price (OP). $\beta_{1}$ represents the estimated long-run parameters and $\alpha_{1}$ shows the speed of adjustment in each equation. Numbers in parentheses are t-statistics where $* * *$, $* *$, and $*$ denote significance at the 1,5 , and $10 \%$, respectively

industrialized countries, economic development leads to higher nuclear energy demand (Lee and Chiu 2011a). ${ }^{9}$ The

\footnotetext{
${ }^{9}$ In 2008, the government introduced New National Energy Strategy in light of global developments, which was heavily focused on achieving energy security. Under this strategy, the government targeted to improve energy efficiency to $30 \%$, increase share of electric power generated from nuclear energy to $30-40 \%$, cut down the oil dependency ratio to about 80 oil exploration and related development projects (Sami 2011).
} 


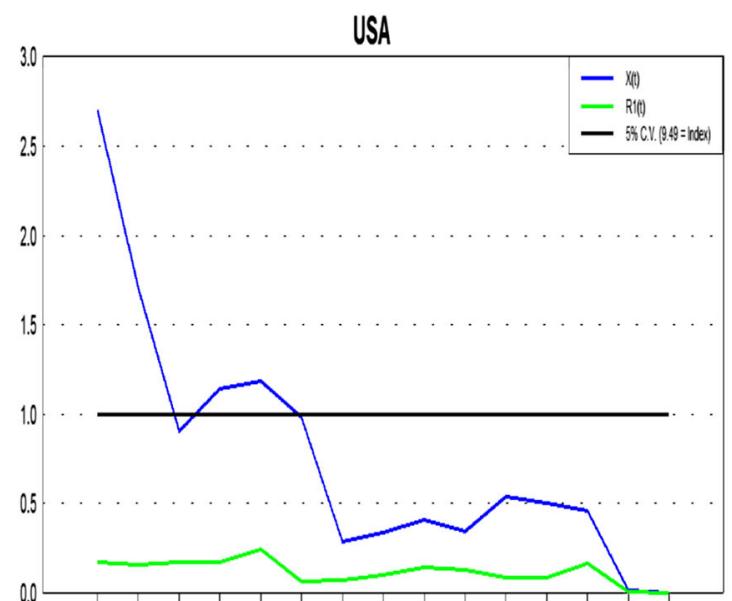

$1996 \quad 1907 \quad 1998 \quad 199920002001200220032004200520062007200820092010$

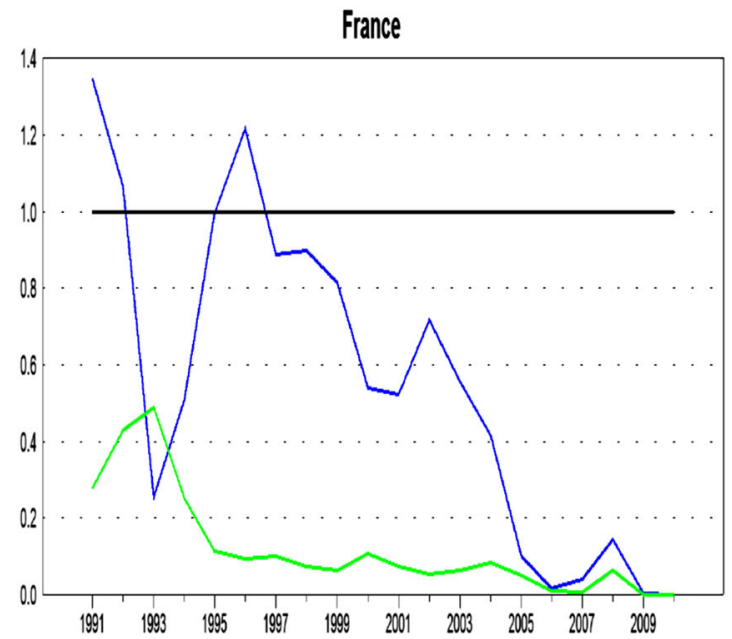

Fig. 2 Hansen and Johansen (1999) test of constancy of $\hat{\beta}$. Notes the figure shows the time path of the tests for $\hat{\beta}$ scaled by the $5 \%$ critical values. The $\mathrm{X}$-form is represented by the blue line and the R-form by

estimated technological change impact on GDP growth is $0.12 \%$ for every $1 \%$ increase.

In France, the long-run relationship includes both energy sources (oil and nuclear power), trend and economic growth. These findings suggest that the process of economic development in France is heavily dependent on both oil and nuclear energy consumption, and the rate of technical change. An increase of $1 \%$ in oil consumption increases the real GDP by $0.262 \%$, and an increase of $1 \%$ in nuclear energy consumption increases the real GDP by $0.049 \%$. The coefficient on the time trend component reveals that the rate of technical change in France improves the real GDP by $0.11 \%$.

The error correction terms, $\alpha_{1}$, shown in Table 9 are with the expected sign (negative) and highly significant for all the investigated countries, except for nuclear energy consumption equation in Japan. The magnitude of loading

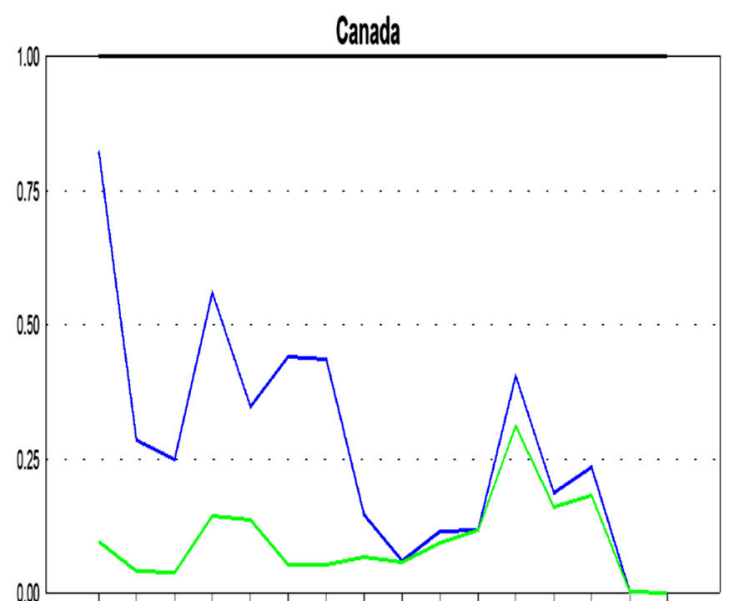

1995199619991998109920002001200220032004200520062007200820092010

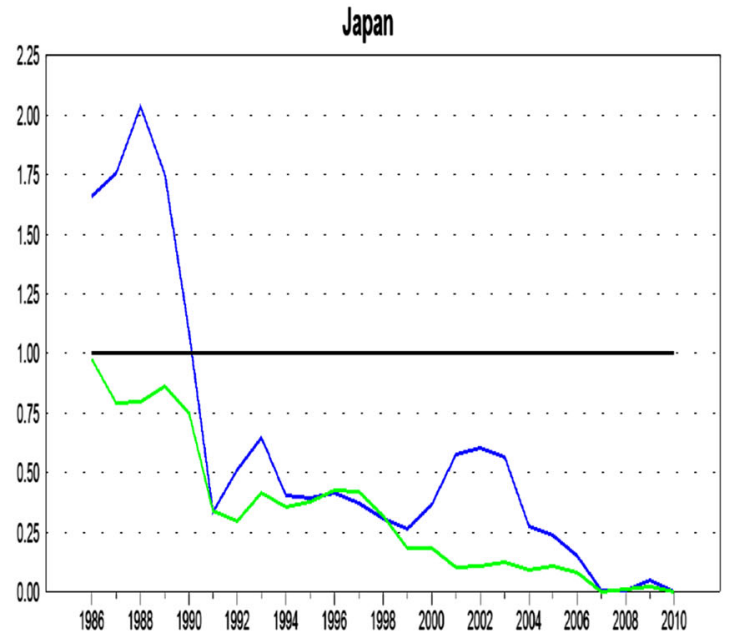

the green line. The $x$-axis shows the year, while the $y$-axis represents the changes in the estimated coefficients over time

factors, $\alpha_{1}$, shows the speed of adjustment to disequilibrium from its long-run equilibrium value. On this basis, it can be seen that when per capita real GDP deviates from its long-run trend, $28,5,35$, and $32 \%$ of that deviation will be corrected within a year for the USA, Canada, Japan, and France, respectively. Thus, the speed of adjustment in the case of any shock to the real GDP equation is sufficiently fast and supports the notion that there is a reasonable control over economic growth, except for Canada.

Furthermore, bidirectional causality hypothesis in the long-run can be tested by the significance of the speed of adjustment, $\alpha_{1}$, in Table 9. The t-statistics of the coefficients of the error correction term (ECT) is used to examine the existence of long-run causal effects. There is a strong evidence that there is a bidirectional causal linkage between oil price and economic growth in the USA, which is in line with the finding of Hamilton (1983) for the USA, 
Alpha 1 (R1-model)
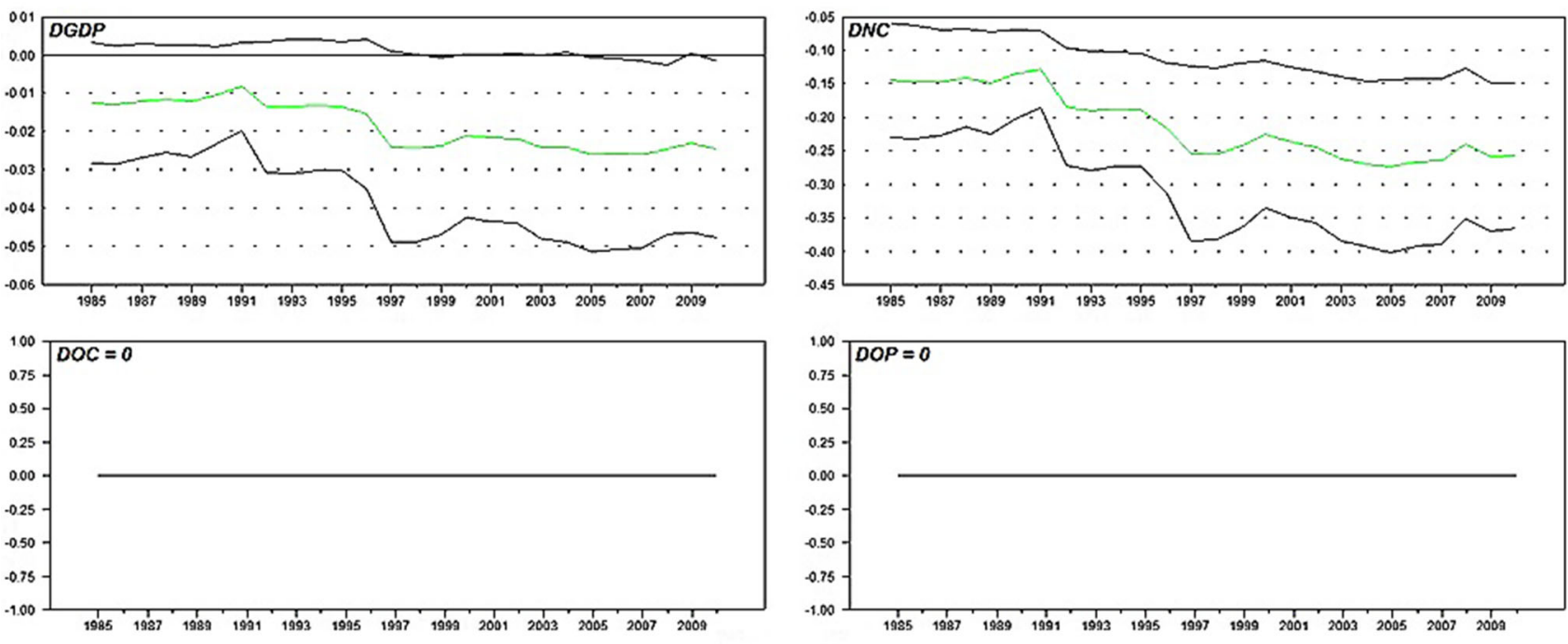

Canada
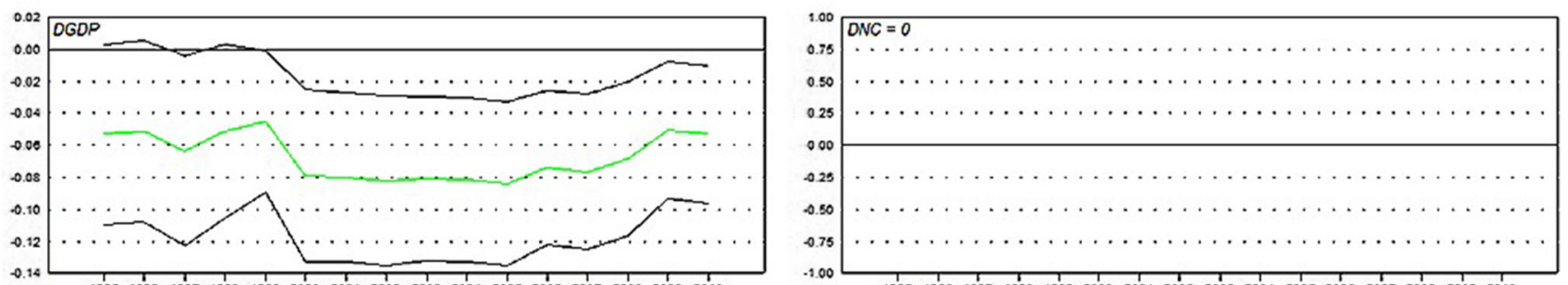

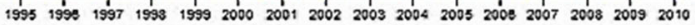

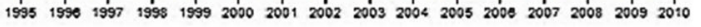
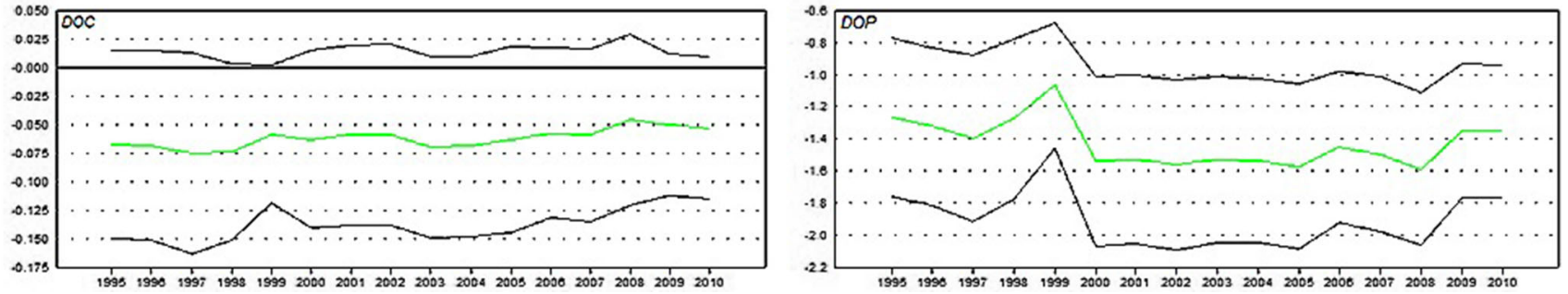

Fig. 3 Hansen and Johansen (1999) test of constancy of $\hat{\alpha}$. Notes the figure presents the estimated time path for $\hat{\alpha}$, where the $x$-axis shows the year and $y$-axis represents the stability of the loading coefficients of the VECM

and Lee and Chiu (2011b) for heterogenous panel analysis. In Canada, results show that there is bidirectional causality between oil consumption and economic growth at $10 \%$ significance level, which is in line with Ghali and El-Sakka (2004). Oil prices, also, have feedback effect on Canadian real GDP growth in the long run. These findings denote that an increase in Canadian economic growth may lead to increase the demands for oil in the long run and that the policies for reducing oil consumption may retard economic growth. Also, upsurge in international prices of oil may directly affect the level of economic growth in Canada. Alternatively, Japan results suggest the existence of a bidirectional relationship between nuclear energy consumption and economic growth, suggesting that nuclear energy use derives economic growth and that economic growth for Japan needs to use more nuclear power. Our finding of a bidirectional causality running between nuclear energy consumption and economic growth in Japan is not in line with the no causality found by Payne and Taylor (2010) for the USA. The divergence of our results from Payne and Taylor (2010) may not only be due to the time period covered and the difference in the sources of the data, it may be differed as a result of the methodologies used in each analysis. Here, it is worth noting that Lee and Chiu (2011a) have found that an increase of $1 \%$ in Japanese income rises nuclear energy consumption by $1.436 \%$. They argued that countries with higher income levels are more likely to have their basic needs and are concerned with environmental problems, as well as they have more money to invest in nuclear energy development. The speed of 


\section{France}
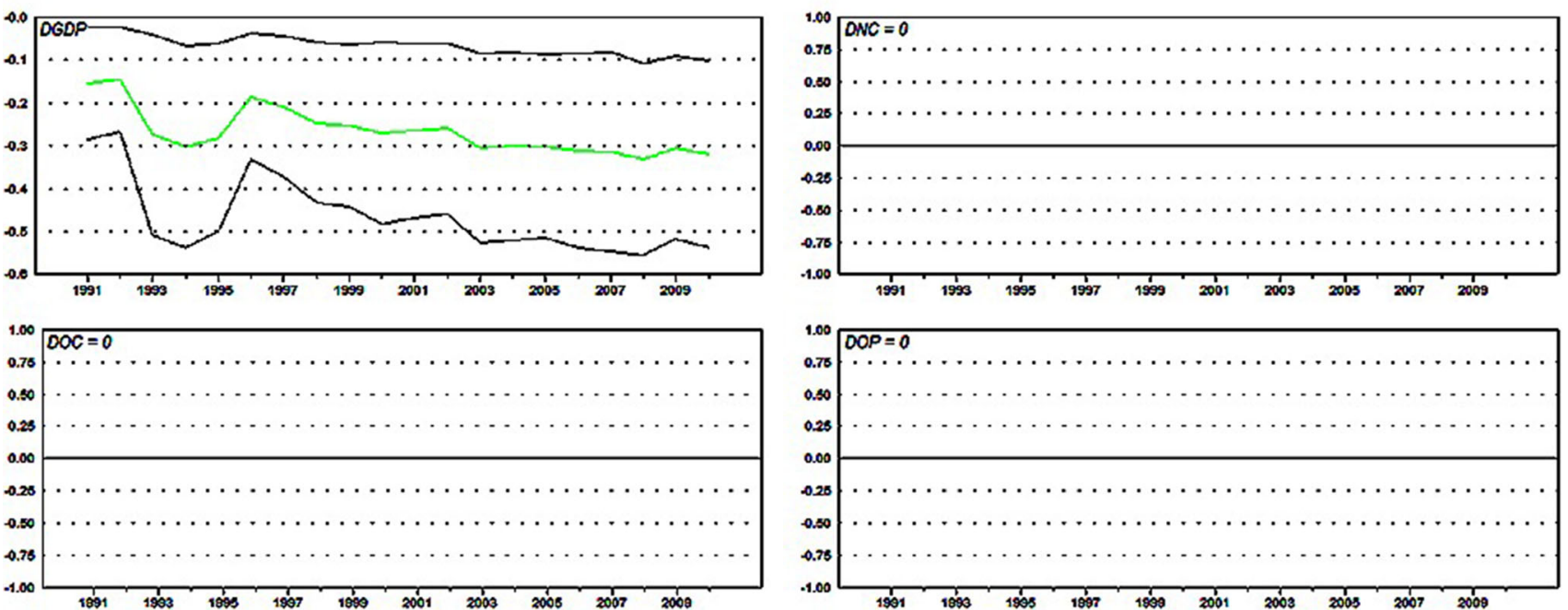

Japan
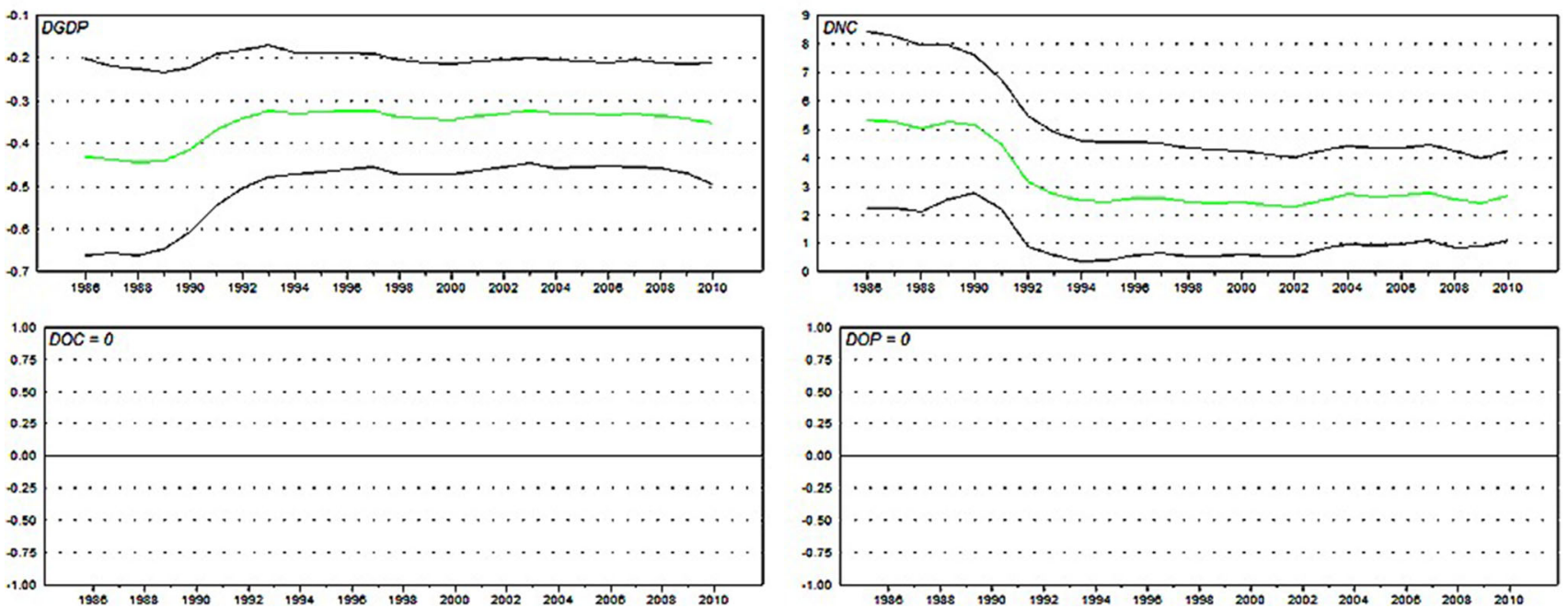

Fig. 4 Hansen and Johansen (1999) test of constancy of $\hat{\alpha}$. Notes The figure presents the estimated time path for $\hat{\alpha}$, where the $x$-axis shows the year and $y$-axis represents the stability of the loading coefficients of the VECM

adjustment to disequilibrium is moderately high in France economic growth model, supporting long-run causality running from oil consumption, nuclear energy consumption, and real oil price to economic growth.

\subsection{Results of stability test}

Hansen and Johansen (1999) propose a multivariate recursive procedure to evaluate the constancy of both the cointegration space and the loadings of the cointegration vector. Figure 2 shows the output of the former and consists of a graph where values over unity imply that there is a change in the cointegration space for a given cointegration rank. This test is performed using either $\mathbf{X}$ or its $\mathbf{R}$ representation. In the former, the recursive estimation is performed by re-estimating all parameters in the VECM, while in the later the dynamics are fixed and only the longrun parameters are recursively estimated. Thus, the rerepresentation is more suitable when the constancy of the long-run parameters is tested. The results support the existence of a stable long-run relationship although there is some instability when the short- and long-run parameters are estimated for most of the cases.

Figures 3 and 4 present the test for the stability of the adjustment coefficients of the VECM with asymptotic 95\% error bounds. This test is performed once the cointegration space has been uniquely identified, and allows one to test whether the responses of the variables to of the variables to long-run disequilibrium are stable over time. The results suggest that the adjustment coefficients are stable. 


\section{Conclusion and policy implications}

To minimize the threats associated with international crude oil prices' shocks and oil supply shortages, the priority of energy policy for many countries has become diversifying the sources of energy and finding a stable, safe, and clean energy supply. One such substitute, which fits these conditions, is nuclear energy. Therefore, one important emerging issue of energy consumption and economic development is 'whether nuclear energy could replace oil and become an important factor for countries' industrialization in the future.' Many studies in the existing literature may suffer from the omission variable bias. To improve any rise to this potential bias, in addition to real GDP this study also incorporates real oil price and oil consumption into our empirical analysis. The Johansen cointegration technique is applied to investigate the interrelationship among oil consumption, nuclear energy consumption, real oil price, and real economic growth in four industrialized countries (the USA, Canada, Japan, and France) for the period 1965-2010. Preliminary tests have shown that all variables are non-stationary at level and the selection of optimal lag length is different from country model to another. However, Johansen Cointegration test shows that there is one cointegration vector in the space of long-run relationship for each country.

Key results of this empirical analysis can be summarized in five folds. First, we find that a long-run relationship exists between economic growth and at least one energy source (oil or nuclear energy) in each country model, which implies that energy is an essential factor for production in all countries included in our sample. Second, results show that oil consumption enters significantly in the cointegration space of the USA, Canada, and France. Third, findings reveal that nuclear energy consumption has a positive and significant impact on real GDP growth in both Japan and France, where increasing nuclear energy consumption by $1 \%$ increases the economic growth for Japan and France by 0.108 and $0.262 \%$, respectively. Fourth, in terms with causality, oil consumption has a predictive power for real GDP in the USA, Japan, and France. In contrast, there is a bidirectional causality between oil consumption and economic growth in Canada. Increasing oil consumption in Canada by $1 \%$ increases the GDP growth by $3.1 \%$. Finally, nuclear energy consumption has predictive power for real economic growth in the USA, Canada, and France, while a bidirectional causal relationship between nuclear energy consumption and real GDP growth is exist in Japan, implying that energy conservation measures taken may negatively affect economic growth.

Our empirical findings have major policy implications, especially that results suggest that the investigated countries are highly dependent on energy consumption to stimulate economic growth. These findings reveal that high level of economic growth leads to a high level of energy demand and/or vice versa, which has a number of implications for policy analysts and forecasters. In order to deal with the lately concerns about the reliance on fossil fuels and not adversely affect economic growth, energy conservation policies that aim to curtailing energy use have to rather find ways of reducing demand on fossil fuel. Efforts must be made to encourage industries to adapt technology that minimize pollution. Alternatively, there is a keen interest in developing nuclear energy in many countries as a mean of ensuring energy security, reducing emissions, coping with the increase in energy demand all over the world, and stabilizing oil price. In addition, the nuclear energy industry plays an important role in job creation and economic growth, providing both near-term and lasting employment and economic benefits. For example, the nearly 100 reactors in the USA generate substantial domestic economic value in electricity sales and revenue of $\$ 40$ billion to $\$ 50$ billion each year, with more than 100,000 workers contributing to that production.

However, since nuclear safety is a global concern that needs a global solution, threats associated with nuclear power should be taken into accounts. There are a lot of advantages and disadvantages from using a such energy source. This indeed an important issue for policymakers, where they have to understand how challenging is the public attitude toward nuclear power in different countries before they revise existing nuclear policies. Operational experience in producing nuclear energy and political pressure on the media are also important to control the informational bias for each country. Hence, the right balance should be struck between the quest of economic growth, nuclear safety, clean energy, and the drive toward making these countries relatively energy independent.

\section{References}

Akarca AT, Long TV (1980) Relationship between energy and gnp: a reexamination. J Energy Dev 5(2):326-331

Al-Iriani MA (2006) Energy-gdp relationship revisited: an example from gcc countries using panel causality. Energy Policy 34(17):3342-3350

Apergis N, Payne J, Menyah K, Wolde-Rufael Y (2010) On the causal dynamics between emissions, nuclear energy, renewable energy, and economic growth. Ecol Econ 69(11):2255-2260

Apergis N, Payne JE (2010a) Energy consumption and growth in south america: evidence from a panel error correction model. Energy Econ 32(6): 1421-1426

Apergis N, Payne JE (2010b) A panel study of nuclear energy consumption and economic growth. Energy Econ 32(3):545-549

Apergis N, Payne JE (2010c) Structural breaks and petroleum consumption in us states: are shocks transitory or permanent? Energy Policy 38(10):6375-6378 
Arestis P, Demetriades P, Fattouh B, Mouratidis K (2002) The impact of financial liberalization policies on financial development: evidence from developing economics. Int $\mathrm{J}$ Finance Econ 7(2):109-121

Arestis P, Demetriades PO, Luintel KB (2001) Financial development and economic growth: the role of stock markets. J Money Credit Bank 33(1):16-41

Chu H, Chang T (2012) Nuclear energy consumption, oil consumption and economic growth in g-6 countries: Bootstrap panel causality test. Energy Policy

Dagher L, Yacoubian T (2012) The causal relationship between energy consumption and economic growth in lebanon. Energy Policy 50:795-801

Dickey D, Fuller W (1979) Distribution of the estimators for autoregressive time series with a unit root. J Am Stat Assoc 74(366a):427-431

Dudley B (2011) BP statistical review of world energy. BP Lond 45

Energy Information Administration (EIA) (2009) http://www.eia.doe. gov/cneaf/electricity/page/sales_revenue.xlsS

Fiore K (2006) Nuclear energy and sustainability: understanding iter. Energy Policy 34(17):3334-3341

Ghali KH, El-Sakka MI (2004) Energy use and output growth in canada: a multivariate cointegration analysis. Energy Econ 26(2):225-238

Granger CW (1988) Some recent development in a concept of causality. J Econom 39(1):199-211

Hamilton JD (1983) Oil and the macroeconomy since world war II. J Polit Econ 228-248

Hansen H Johansen S (1993) Recursive estimation in cointegrated var-models. manuscript, Institute of Economics, University of Copenhagen

Hansen H, Johansen S (1999) Some tests for parameter constancy in cointegrated var-models. Econ J 2(2):306-333

Huang B-N, Hwang M, Yang C (2008) Does more energy consumption bolster economic growth? an application of the nonlinear threshold regression model. Energy Policy 36(2):755-767

IEA (2008) World Energy Outlook 2008. International Energy Agency, Paris, France

IFS (2009) International Financial Statistics Yearbook 2009

Jobert T, Karanfil F, Tykhonenko A (2013) On the structure and form of the gdp-nuclear nexus: new perspectives and new findings. Energy Policy 62:1553-1561

Johansen S (1988) Statistical analysis of cointegration vectors. J Econ Dyn Control 12(2):231-254

Johansen S (1992) Testing weak exogeneity and the order of cointegration in uk money demand data. J Policy Model 14(3):313-334

Johansen S (1996) Likelihood-based inference in cointegrated vector autoregressive models

Johansen S, Juselius K (1990) Maximum likelihood estimation and inference on cointegration - with applications to the demand for money. Oxf Bull Econom Stat 52(2):169-210

Kraft J, Kraft A (1978) Relationship between energy and gnp. J Energy Dev 3(2):401-403

Kwiatkowski D, Phillips P, Schmidt P, Shin Y (1992) How sure are we that economic time series have a unit root. $\mathrm{J}$ Econom 54:159-178

Lee C, Chiu Y (2011a) Nuclear energy consumption, oil prices, and economic growth: evidence from highly industrialized countries. Energy Econ 33(2):236-248

Lee C, Chiu Y (2011b) Oil prices, nuclear energy consumption, and economic growth: new evidence using a heterogeneous panel analysis. Energy Policy 39(4):2111-2120

Lee C-C (2006) The causality relationship between energy consumption and gdp in g-11 countries revisited. Energy Policy 34(9):1086-1093
Lütkepohl H (1993) Introduction to multivariate time series analysis

Lüutkepohl H, Saikkonen P, Trenkler C (2001) Maximum eigenvalue versus trace tests for the cointegrating rank of a VAR process. Econ J 4(2):287-310

Mahadevan R, Asafu-Adjaye J (2007) Energy consumption, economic growth and prices: a reassessment using panel vecm for developed and developing countries. Energy Policy 35(4):2481-2490

Mehrara M (2007) Energy consumption and economic growth: the case of oil exporting countries. Energy Policy 35(5):2939-2945

Menyah K, Wolde-Rufael Y (2010) Energy consumption, pollutant emissions and economic growth in south africa. Energy Econ 32(6): 1374-1382

Naser H (2014) Oil market, nuclear energy consumption and economic growth: evidence from emerging economies. Int $\mathrm{J}$ Energy Econ Policy 4(2):288

Naser H (2015a) Analysing the long-run relationship among oil market, nuclear energy consumption, and economic growth: An evidence from emerging economies. Energy 89:421-434

Naser H (2015b) Can nuclear energy stimulates economic growth? Evidence from highly industrialised countries. Int J Energy Econ Policy 5(1): 164

Nazlioglu S, Lebe F, Kayhan S (2011) Nuclear energy consumption and economic growth in oecd countries: cross-sectionally dependent heterogeneous panel causality analysis. Energy Policy 39(10):6615-6621

OPEC (2012) World Oil Outlook. Organisation of Petroleum Exporting Countries

Ozturk I (2010) A literature survey on energy-growth nexus. Energy Policy 38(1):340-349

Payne J, Taylor J (2010) Nuclear energy consumption and economic growth in the us: an empirical note. Energy Sour B Econ Plan Policy 5(3):301-307

Pesaran MH, Pesaran B (1997) Working with microfit 4.0: interactive econometric analysis. Oxford University Press, Oxford

Phillips P, Perron P (1988) Testing for a unit root in time series regression. Biometrika 75(2):335-346

Sami J (2011) Multivariate cointegration and causality between exports, electricity consumption and real income per capita: Recent evidence from japan. Int $\mathrm{J}$ Energy Econ Policy 1(3):59-68

Sari R, Soytas U (2004) Disaggregate energy consumption, employment and income in turkey. Energy Econ 26(3):335-344

Stern DI (2000) A multivariate cointegration analysis of the role of energy in the us macroeconomy. Energy Econ 22(2):267-283

Vaillancourt K, Labriet M, Loulou R, Waaub J-P (2008) The role of nuclear energy in long-term climate scenarios: an analysis with the world-times model. Energy Policy 36(7):2296-2307

Vaona A (2012) Granger non-causality tests between (non) renewable energy consumption and output in italy since 1861: the (ir) relevance of structural breaks. Energy Policy 45:226-236

WDI (2011) World Development Indicators. Online Database

Wolde-Rufael Y (2010) Bounds test approach to cointegration and causality between nuclear energy consumption and economic growth in india. Energy Policy 38(1):52-58

Wolde-Rufael Y, Menyah K (2010) Nuclear energy consumption and economic growth in nine developed countries. Energy Econ 32(3):550-556

Yoo S-H, Jung K-O (2005) Nuclear energy consumption and economic growth in korea. Prog Nucl Energy 46(2):101-109

Yoo S-H, Ku S-J (2009) Causal relationship between nuclear energy consumption and economic growth: a multi-country analysis. Energy Policy 37(5):1905-1913 